\title{
Diseases and Disease Management Strategies Take Top Research Priority in the Watermelon Research and Development Group Members Survey (2014 to 2015)
}

Chandrasekar S. Kousik, USDA, ARS, U.S. Vegetable Laboratory, Charleston, SC 29414; James Brusca, Syngenta Seeds, Inc., Woodland CA 95695 (present address: HM.Clause, Davis, CA 95618); and William W. Turechek, USDA, ARS, U.S. Horticultural Research Laboratory, Ft. Pierce, FL 34945

Accepted for publication 23 March 2016. Published 29 March 2016.

\section{ABSTRACT}

Kousik, C. S., Brusca, J., and Turechek, W. W. 2016. Diseases and disease management strategies take top research priority in the Watermelon Research and Development Group members survey (2014 to 2015). Plant Health Prog. 17:53-58.

Watermelon is an important crop grown for its fruit in the United States and many other countries across the world. A survey of members of the Watermelon Research and Development Group was conducted (2014 to 2015) to identify and rank research priorities. Participants were asked to assign a ranking from 1 to 10 for 25 listed priorities with 1 being most important. Priorities were partitioned into five groups on the basis of the results of several complementary analyses. Based on 30 respondents included in the final analysis, diseases and strategies for their management were identified as the most important research priorities. Fusarium wilt and host resistance to gummy stem blight were considered top priorities and were included in group 1. Group 2 included bacterial fruit blotch, anthracnose resistance, Cucumber green mottle mosaic virus, fruit yield, improved post-harvest fruit quality, and powdery mildew. Group 3 included seedless pollination, Phytophthora fruit rot, seedless hybrid production, hollow heart, downy mildew, firm flesh, and sugar content. Grafting methods, various viral diseases, and whitefly resistance were included in the 4th group. All write-in priorities fell into the 5th group. The present survey results indicates that research efforts should be directed towards developing solutions for managing important watermelon diseases.

\section{INTRODUCTION}

Watermelon is an important crop grown on 120,000 acres (48,560 hectares) in 44 states in the United States (USDA NASS 2015). The total U.S. watermelon production in 2014 was 1.5 million metric tons $(31,952 \mathrm{CWT})$ valued at \$431 million. Globally, nearly three-quarters of the world's watermelon production occurs in Asia, with China being the leading watermelon producer. Watermelon is generally eaten as fresh fruit, but can also be eaten as pickled rind, glacé candy, and roasted seeds. In the United States, watermelon is mainly consumed as a fresh fruit during the summer months; however, it is available in the market throughout the year. The fruit come in various shapes and sizes, with a variety of flesh colors. The key nutritional components of watermelon fruit are carbohydrates, vitamin A, lycopene, and citrulline (USDA National Nutrient Database, Release 26, 2013; Kousik et al. 2015a). Lycopene, considered an anticarcinogenic compound, is found in red-fleshed watermelon, with some of the dark-red-fleshed varieties having higher lycopene content than tomatoes (Perkins et al. 2001). In 2012 , over $90 \%$ of the watermelons consumed in the United States were seedless varieties.

There are various factors that limit watermelon production, but diseases are key. There are numerous diseases that affect watermelon production throughout the United States, including

Corresponding author: C. S. Kousik (Shaker). Email: shaker.kousik@ars.usda.gov.

doi:10.1094/PHP-S-15-0047

(C) 2016 The American Phytopathological Society
Fusarium wilt, gummy stem blight, several different fruit rots, anthracnose, powdery and downy mildews, bacterial fruit blotch, and a number of viruses. Insects that can transmit viruses, such as whiteflies and aphids, can similarly affect production. Other factors that limit production include poor pollination, hollow heart, and low sugar content (brix).

It is useful for any commodity group to regularly survey its constituency to determine how to prioritize the factors limiting production to help guide research efforts. In the United States, there are three main groups that are concerned with watermelon production. One is the Watermelon Research and Development Group (WRDG) that mainly consists researchers and product development specialists from the seed industry (including breeders and seeds sales force, 39\%), university research and extension faculty (49\%), and USDA ARS and other government scientists (12\%). Another group is the National Watermelon Association (NWA), which is mainly composed of growers, shippers, and packers (handlers), buyers from super markets, brokers, importers, seed sales personnel, and University researchers from across the United States. The third group is the National Watermelon Promotion Board (NWPB), which is funded through assessments from a checkoff program. Most members of NWA are generally members of NWPB and most members of WRDG work with members of NWA and NWPB. The NWA generally conducts a simple one-question survey every year requesting that the growers point out their most important problem, which helps channel their research funding appropriately. More comprehensive surveys, however, are typically conducted by the WRDG (King and Davis 2006). 
The focus of this research was to identify the top research priorities identified by the most recent member survey of the WRDG and compare these results to prior surveys of the WRDG and NWA.

\section{SURVEY INSTRUMENT}

Based on discussions with the membership at the annual WRDG meeting held during February 2014, a simple questionnaire listing 25 research priorities was developed (Table 1). These included watermelon diseases, disease management strategies, insect pests, horticultural traits, and other research needs that were suggested by members during the 2014 meeting in February. The research priorities were listed randomly on the questionnaire to avoid selection bias based on a priorities position. The questionnaire was initially sent via email to survey all the members of WRDG; due to a limited response to the email survey, the same questionnaire was printed and provided to the members during the WRDG special meeting held as part of Cucurbitaceae 2014 in Bay Harbor, MI, in October, and again during the WRDG annual meeting in Atlanta in January 2015. Only members who had not attended the meeting in Bay Harbor, MI, were permitted to complete the survey in Atlanta. The members were requested to

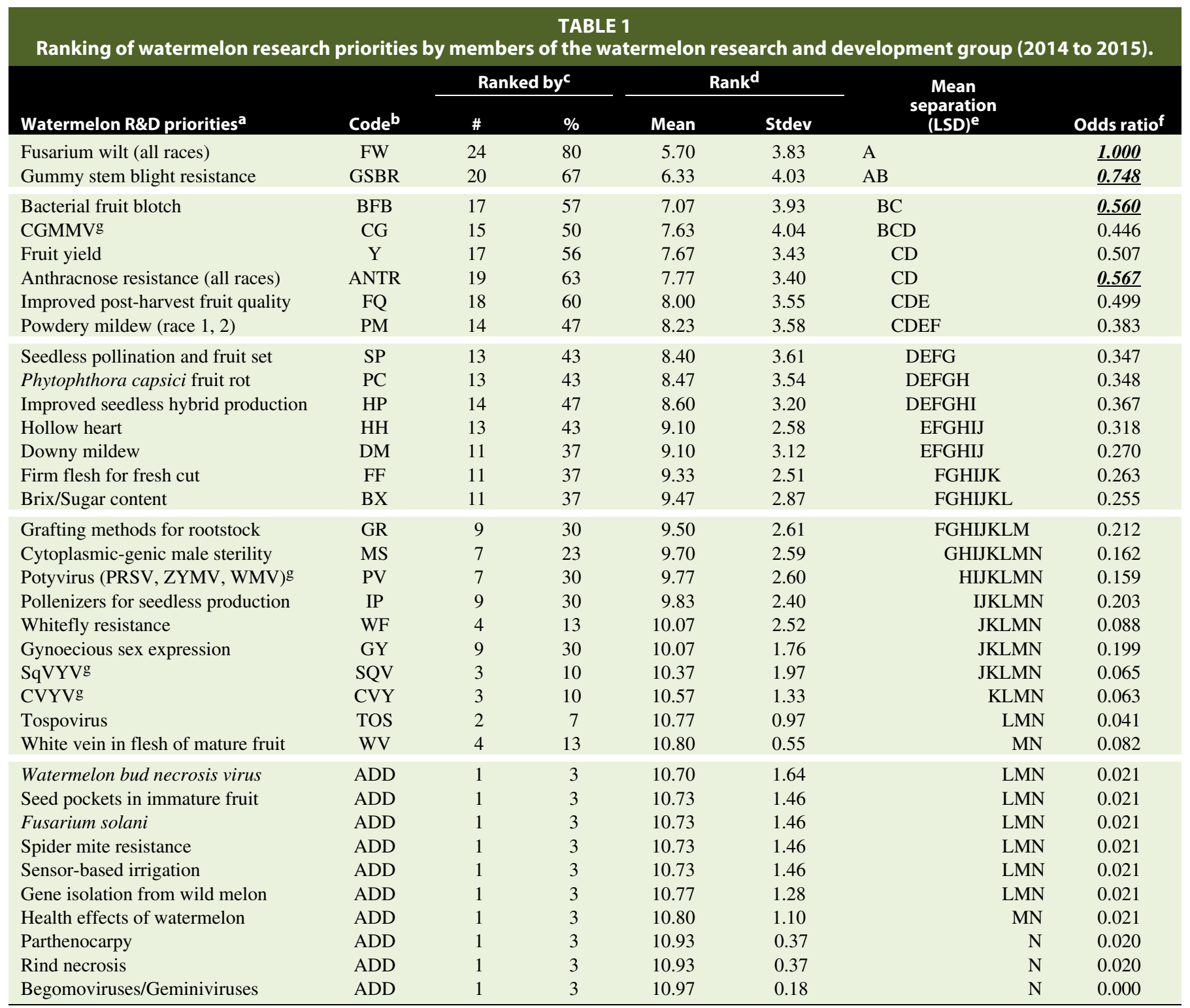

${ }^{a}$ Watermelon research priorities listed were based on a discussion held at the WRDG meeting in February 2014.

${ }^{\mathrm{b}}$ Survey participants had space to write in (ADD) a priority they considered important if it was not listed. The codes for the other priorities correspond to the codes in Figure 1.

${ }^{\mathrm{c}}$ The number and percentage of participants out of 30 who considered it important enough to rank a given priority.

${ }^{d}$ Mean and standard deviation of the survey participants ranks for the listed priorities. Participants were asked to rank the priorities from 1 to 10 with 1 being the most important. Unranked priorities were given a rank of 11.

e Mean separation is based on Fisher's least significant difference ( $\left.\operatorname{LSD}_{0.05}\right)$.

${ }^{\mathrm{f}}$ Odds ratios represent the proportional decrease in odds of being selected over Fusarium wilt. Priorities in boldface type are not significantly different from Fusarium wilt.

$\mathrm{g}$ The full names of the abbreviations for the viruses are as follows: CGMMV=Cucumber green mottle mosaic virus; PRSV=Papaya ringspot virus; $\mathrm{ZYMV}=$ Zucchini yellow vein mosaic virus; $\mathrm{WMV}=$ Watermelon mosaic virus; $\mathrm{SqVYV}=$ Squash vein yellowing virus; $\mathrm{CVYV}=$ Cucumber vein yellowing virus. 
assign a rank from 1 to 10 to the top ten priorities they felt were important, with 1 being the most important. Blank columns were also provided for members to write in other priorities that they thought were important but not listed (Table 1).

\section{STATISTICAL ANALYSIS AND SURVEY RESULTS}

The WRDG has over 100 U.S. and international members, of which 41 members responded to the survey. Both the email and the printed surveys were included in the analysis. The initial survey listed 25 priorities; however, after the write-in priorities were tallied, a total of 40 priorities were identified. All 25 priorities that were initially listed were ranked by at least two members of the group.

For analysis, the data was processed to eliminate respondents who did not correctly follow directions, e.g., priorities were all ranked by the same value or rated fewer than eight items. The final data set consisted of rankings from 30 respondents for 34 priorities. Six of the write-in priorities were associated with respondents who did not correctly follow the directions for ranking the priorities and these were not included in the final analysis. The overall percentage of the initial 41 respondents who considered a priority important enough to rank was very similar to the data from the 30 respondents whose ratings were selected for the final analysis. It is important to note that the intent of the survey was mainly to determine what was considered important by most in the group. Individual priorities that were not ranked highly or not in the top priority grouping (discussed later) can still be extremely important in a particular region or for a particular individual. Respondents were also asked to indicate their region; however, most of them failed to do so.

The data was analyzed in several steps. First, a multidimensional preference analysis (MDPREF) was conducted to determine how priorities grouped relative to the respondents preferences (SAS User's Guide, SAS Institute Inc., Cary, NC; see page 2807 for an example). The MDPREF analysis was conducted using the SAS procedure PRINQUAL. MDPREF is based on the principal component model but is specific for variables that are ordinal preference ratings. Results of the analysis are shown as a bi-plot of the first two principal components. The raters are represented as vectors that emanate from the origin and point in the direction of their most preferred priority. Priorities are represented as points with the most preferred priorities (on average) being located on one side of the plot and the least preferred on the other side. Results of this analysis clearly indicated that a majority of respondent's ranked diseases and their management strategies, particularly Fusarium wilt and host resistance to gummy stem blight (GSBR), as important priorities (Fig. 1). Fusarium wilt was ranked in the top ten priorities by $80 \%$ of the respondents followed by GBSR by $67 \%$, host resistance to anthracnose (anthracnose resistance) by $63 \%$, and bacterial fruit blotch (BFB) by $57 \%$. Research for improved post-harvest fruit quality $(60 \%)$ and improved fruit yield $(56 \%)$ were also considered important by the respondents. Cucumber green mottle mosaic virus (CGMMV) was ranked by $50 \%$ and powdery mildew by $47 \%$ of the respondents.

Next, an exploded logit model was fit to the data to estimate which of the priorities predict rater preference (Allison 2012). For this and the MDPREF analyses, the ordering of the ranks was reversed to give the top ranking priority a value of 10 and the lowest ranked priority a value of 1 . All unranked priorities were considered as ties with a rank 0 , naturally following the lowest ranked priority of 1 . Priority was labelled as a class variable and the priority "Fusarium wilt" was chosen as the reference class for constructing the odds ratios. This priority was chosen because it had the highest average rank among all priorities; thus, odds ratios represent the proportional decrease in odds of being selected over Fusarium wilt. Similar to the MDPREF analysis, results showed that diseases and their management strategies garnered the highest priority (Table 1). Host resistance to gummy stem blight (GSBR), bacterial fruit blotch (BFB), and host resistance to anthracnose (anthracnose resistance) have odds ratios that were not statistically different from Fusarium wilt. For example, GSBR has $25.2 \%$ lower odds of being ranked higher than Fusarium wilt. CGMMV, powdery mildew, and Phytophthora capsici also had relatively high odds ratios among the diseases, along with yield, post-harvest quality, and seedless pollination for horticultural traits. The exploded logit model was fit using the SAS procedure PHREG.

The last analysis was a simple one-way ANOVA of the ranks. For this analysis, the original numerical rankings were used, and unranked items were ranked as " 11 ." This analysis is akin to performing the nonparametric Kruskall-Wallis test, but was chosen over the latter to allow easy application of the Fisher's least significant difference test (LSD) on the results. The nonparametric equivalent, the Dunn's test, exists as an SAS macro (also a Minitab macro), but the authors of these macros built a limit to allow separation of only 20 medians (or 25 for Minitab). Results indicated significant differences among mean ranks $(P<0.0001)$. The mean ranks separated into several overlapping groups. The two smallest groupings encompassed four priorities: Fusarium wilt; GSBR; bacterial fruit blotch; and CGMMV. The ANOVA was conducted using the SAS GLM procedure.

\section{WATERMELON RESEARCH PRIORITY GROUPINGS}

The percentage of respondents ranking a given priority, the mean ranks, and the odds ratios were used to classify the watermelon research priorities into five groups. Since each of the procedures separated the mean rank into several overlapping groups, the three sets of results were taken together to create the five groups using the authors' expertise to create boundaries. Since it was not possible to group the watermelon research

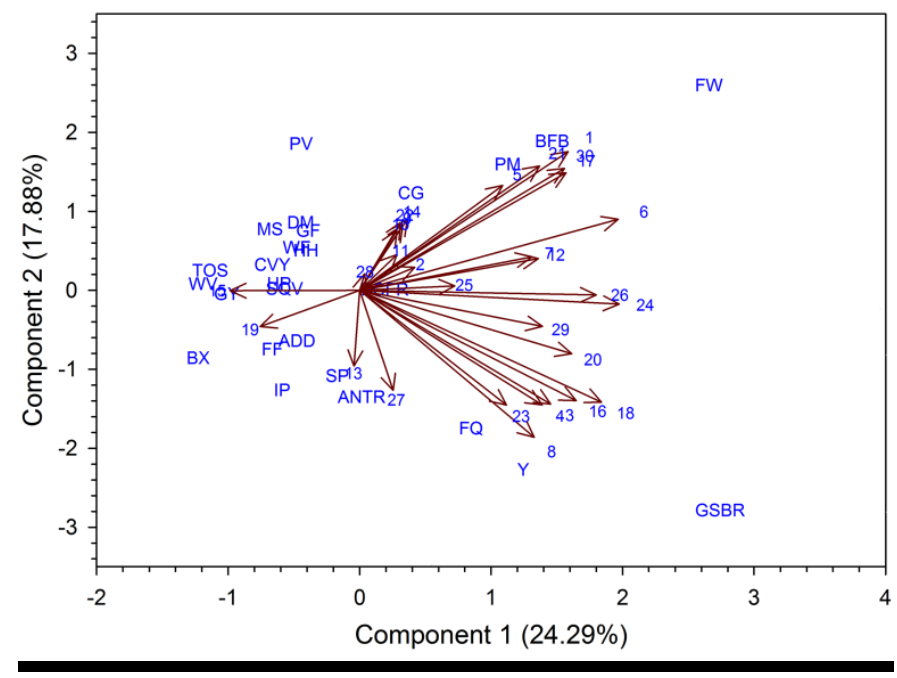

FIGURE 1

Results of the multidimensional preference analysis. Results are shown as a biplot of the first two principal components with raters being represented as vectors that originate from the origin and point in the direction of their most preferred priority. Priorities are shown as their coded names points (Table 1, code) with the most preferred priorities being located towards the right-hand side of the plot and the least preferred on the left-hand side. 
priorities into distinct groups, it should be noted that priorities at either end of a grouping could have just as easily belonged in the neighboring group.

Group 1. The first group contained Fusarium wilt and GSBR. These two priorities consistently ranked first and second respectively, based on the odds ratio, mean rank, and the percentage of respondents ranking them. The MDPREF analysis (Fig. 1) also distinctly separated out these two research priorities. Details of these two top research priorities are provided below.

Fusarium wilt. Fusarium wilt of watermelon caused by Fusarium oxysporum f. sp. niveum was ranked as the top research priority in the present survey, which is not surprising, as it is the most commonly reported soil-borne disease on watermelon worldwide (Egel and Marytn 2007; Cohen et al. 2007; Martyn 2014). Fusarium wilt was a top priority for the grower group in a previous survey as well (King and Davis 2006). Fusarium wilt is also mentioned under "needs for disease control in watermelon" in the Pest Management Strategic Plan (PMSP 2008) for watermelons in Delaware, Maryland, New Jersey, and North Carolina. The disease was first reported in the United States from Georgia and South Carolina in 1894 (Martyn 1996, 2014) and since then a significant amount of research has been directed towards it (Martyn 2014). Unfortunately, this disease remains a major limiting factor in watermelon production, likely due to the emergence of new races. Currently, four races of Fusarium oxysporum f.sp. niveum have been identified. Resistance to races 0 and 1 are available in commercial cultivars. Resistance to race 2 has been identified in several plant introductions (Dane et al. 1998; Martyn and Netzer 1991; Netzer and Martyn 1989; Wechter et al. 2012), but is not yet readily available in commercial cultivars (Wechter et al. 2012). A new race, called race 3, was described in Maryland in 2010 (Zhou et al. 2010), and resistance to this race has not yet been identified. Although resistance is the preferred method for disease management, other approaches to help manage Fusarium wilt include crop rotation and use of cover crops such as hairy vetch (Zhou and Everts 2004, 2007). Chemical options to manage Fusarium wilt are limited but do exist, including a new registration to apply prothioconazole through drip irrigation (Everts et al. 2014). Fusarium wilt of watermelon may also be managed by grafting susceptible watermelon on rootstocks belonging to different cucurbit genera (Cohen et al. 2007; Miguel et al. 2004; Davis et al. 2008; Keinath and Hassell 2014). Interestingly, grafting was considered a top research priority in a previous survey (King and Davis 2006).

Gummy stem blight host resistance. The need for host resistance to manage gummy stem blight (GSBR) was ranked as the second most important research priority with fourteen respondents ranking GSBR in their top three research priorities. Its mean rank of 6.33 was not statistically different from Fusarium wilt's ranking according to the logit analysis and LSD. In a previous survey, gummy stem blight was ranked as the most important priority (King and Davis 2006). Gummy stem blight caused by Didymella bryoniae was first reported in 1891 (Keinath 2011; Sitterly and Keinath 1996) and remains a major concern today. Chemical control is the primary method of managing GSB and several fungicides are available (Sitterly and Keinath 1996; Keinath 2001; Keinath et al. 2011; Keinath and Miller 2014). Currently, resistance is not yet available in commercial cultivars; however, several sources of resistance have been identified (Gusmini et al. 2005).

Group 2. The second group of research priorities were ranked in the top ten priorities by 47 to $63 \%$ of respondents with mean ranks that ranged from 7.07 to 8.23 and odds ratios that ranged from 0.383 to 0.567 . Four of the six priorities in this group were diseases or disease management-related and included: Bacterial fruit blotch; CGMMV; host resistance to anthracnose; and powdery mildew. The other two priorities were horticultural traits, namely fruit yield and improved post-harvest fruit quality. Details of the key priorities in the second group are provided below.

Bacterial fruit blotch caused by Acidovorax avenae subsp. citrulli was ranked in the top ten priorities by $57 \%$ of the respondents and its mean rank of 7.07 ranked it third. Based on the odds ratio, bacterial fruit blotch was not significantly different from Fusarium wilt and GSBR and seemed to be a good candidate for inclusion in the first group. However, when considering results of the MDPREF analysis and the percentage of respondents ranking it, we classified it as the top priority in the second group. BFB was first reported from Florida in the United States in 1989 and soon became a significant problem in the early 1990s (Somodi et al. 1991; Latin and Hopkins 1995; Latin 1996). However, during the previous survey, BFB was ranked in the third tier and not considered as important as gummy stem blight (King and Davis 2006). Since then, it appears that this pathogen may be re-emerging as a serious problem and hence it has moved up in priority ranking.

Host resistance to anthracnose (anthracnose resistance) caused by Colletotrichum orbiculare was ranked in the top ten priorities by $63 \%$ of the respondents. This percentage was higher than BFB, but its mean rank of 7.77 was lower than BFB. Ranking for anthracnose resistance was not significantly different from Fusarium wilt, GSBR, or BFB based on odds ratio (Table 1). However, it was different from GSBR and Fusarium wilt based on LSD, where it was then decided to place it in the second group. Similar to BFB, anthracnose seems to be a re-emerging problem in watermelon, mainly because the existing resistance to anthracnose in commercial cultivars does not hold up to the extreme anthracnose pressure that has been observed in recent years.

CGMMV, improved fruit yield, improved post-harvest fruit quality, and powdery mildew (caused by Podosphaera xanthii), with mean ranks ranging from 7.63 to 8.23 , were also placed in the second group along with BFB and anthracnose resistance. CGMMV emerged as a significant problem in recent years on cucurbit crops particularly in California (Tian et al. 2014). Powdery mildew, which was ranked by $47 \%$ of the respondents with a mean rank of 8.23, infects all cucurbits (McGrath and Thomas 1996). It generally has not been considered a major factor in watermelon production, but in recent years the incidence of this disease has been on the rise, particularly in the southeastern states.

Group 3. The third group of research priorities were ranked in the top ten priorities by 37 to $47 \%$ of respondents with mean ranks that ranged from 8.40 to 9.47 and odds ratio that ranged from 0.255 to 0.347 . Phytophthora fruit rot (Phytophthora capsici) with a mean rank of 8.47 and downy mildew (Pseudoperonospora cubensis, mean rank 9.10) were the two diseases in this group. Horticultural traits, including seedless pollination and fruit set, seedless hybrid production, hollow heart, firm flesh for fresh cut market, and brix (sugar content), were also placed in this group of priorities.

Group 4. The fourth group of research priorities were ranked in the top ten priorities by 7 to $30 \%$ of respondents, with mean ranks that ranged from 9.50 to 10.80 and odds ratio that ranged from 0.082 to 0.212 . Some of the priorities listed in this group could easily have fallen at the end of the previous group. However, after considering the mean ranks, percentage of respondents ranking the priority, and the odds ratio, the following were considered as the fourth group: efficient grafting methods 
for rootstock use; cytoplasmic-genetic male sterility; Potyviruses [Papaya ring spot virus (PRSV), Zucchini yellow mosaic virus (ZYMV), and Watermelon mosaic virus (WMV)]; improved pollenizers for seedless production; whitefly resistance; Gynoecious sex expression; Squash vein yellowing virus (SqVYV); Cucumber vein yellowing virus (CVYV); tospoviruses; and the physiological disorder white vein/core in flesh of mature fruit. Efficient grafting methods was considered a top priority by the growers and was the second most important priority overall in the previous survey (King and Davis 2006). However, in the present survey, only $29 \%$ of the respondents ranked it in the top ten priorities, and its mean rank was very low at 9.50. This is probably because grafting watermelons has not yet caught on at a large scale among growers and researchers in the United States.

Group 5. The fifth and the last group mainly consisted of write-in priorities (Table 1, code ADD). Each of these add-ons was ranked by only one respondent, which gave them the minimum $3 \%(\sim 1 / 30)$ response rate. The mean rank for this group ranged from 10.70 to 10.97 and the odds ratio ranged from 0.00 to 0.021. Again, it should be noted that even though these priorities did not rank highly among the entire group, they were considered important enough by at least one member to include them as an important priority. The low rankings may be due to underrepresentation from the region where the problem occurs, or the problem may be sporadic and was not "on the radar" of the majority of respondents. For example, Cucurbit leaf crumple virus $(\mathrm{CuLCrV})$ and Cucurbit yellow stunting disorder virus (CYSDV) are more of a problem on watermelon in Florida (Adkins et al. 2011; Turechek et al. 2010). Similarly, rind necrosis is also an occasional problem and occurs infrequently in some locations. The other priorities not listed in the table but belonging in this group include: host resistance to thrips; nematodes; weeds; and parthenocarpy.

\section{COMPARISON WITH OTHER SURVEY RESULTS}

The NWA conducts a simple, one-question, internal survey of watermelon growers and shippers to determine their researchfunding priorities. According to several recent surveys conducted by NWA, Phytophthora fruit rot caused by Phytophthora capsici was considered the highest priority for research in 2014, 2015, and 2016, mainly because of the severity of the disease in the southern region (North Carolina, South Carolina, and Georgia, Bob Morrisey, personal communication; Kousik et al. 2014) and more recently in northern regions (Indiana, Delaware, and Maryland) of the United States (Kousik et al. 2015c). This is quite different from the results obtained from this survey of members of WRDG, where Phytophthora fruit rot was ranked in the top ten priorities by only $43 \%$ of the respondents achieving a mean rank of 8.47 and placing it in the third group. However, based on LSD, Phytophthora fruit rot was not significantly different from most diseases or disease management strategies placed in the second group including CGMMV, anthracnose resistance, and powdery mildew. In any case, a significant portion $(>60 \%)$ of the funding provided by the NWA in 2014 and 2015 was for research on $P$. capsici. Identifying solutions to manage Phytophthora fruit rot has been the most pressing need for many NWA members. Fusarium wilt was also considered important research priority in the NWA survey and funding was provided for Fusarium wilt research as well.

The results of the NWA survey generally represents the most pressing needs for the growers in a particular year. For example, during 2005 to 2006, watermelon vine decline was considered the most important research priority by the NWA (Morrisey 2006) and most of the NWA research funding was directed towards that effort. However, a previous survey of seed company breeders and growers from Texas conducted around the same time placed SqVYV in the third tier of priorities for research (King and Davis 2006). This could have been because WVD caused by SqVYV in Florida was limited to southwest Florida and hence ranked in the third group in the previous survey and the fourth group in this survey. Nevertheless, a significant amount of research has been conducted on WVD, including identification of the causal agent of WVD in Florida and development of disease management techniques (Adkins et al. 2011; Kousik et al. 2012, 2015b) that the disease has been kept in check for the last several years. Overall, NWA members, like WRDG members, considered watermelon diseases in general as their most important problems affecting production.

\section{CONCLUSIONS}

The present survey of the members of the WRDG clearly identified diseases of watermelon and their management strategies as top research priorities. Fusarium wilt, host resistance to gummy stem blight, bacterial fruit blotch, host resistance to anthracnose, and CGMMV were all considered important priorities. Watermelon growers also consider diseases as the most important production limiting factor as evidenced by the NWA survey. In recent years, the grower groups have regularly funded research directed toward finding solutions for disease management. New and more effective disease management strategies for these diseases are sorely needed and it is hoped a significant amount of research will be directed to that end. Though the above diseases were considered important by the members the WRDG, the growers considered Phytophthora fruit rot as their most important priority. Hence, it is important that we should continue to tackle regional problems as well to help growers produce a successful crop.

\section{ACKNOWLEDGMENTS}

The authors wish to acknowledge all members of the Watermelon Research and Development Group who responded to the survey. We acknowledge the help of Jennifer Ikerd in carefully entering all the data. The authors also wish to thank Dr. W. P. Wechter for critical review of the manuscript prior to submission.

\section{LITERATURE CITED}

Adkins, S., Webster, C. G., Kousik, C. S., Webb, S. E., Roberts, P. D., Stansly, P. A., and Turechek, W. W. 2011. Ecology and management of whiteflytransmitted viruses of vegetable crops in Florida. Virus Res. 159:110-114.

Allison, P. D. 2012. Logistic Regression Using SAS: Theory and Application, 2nd ed. SAS Institute Inc., Cary, NC.

Cohen, R., Burger, Y., Horev, C., Koren, A., and Edelstein, M. 2007. Introducing grafted cucurbits to modern agriculture: The Israeli experience. Plant Dis. 91:916-923.

Dane, F., Hawkins, L. K., and Norton, J. D. 1998. New resistance to Race 2 of Fusarium oxysporum F. sp. niveum in watermelon. Cucurbit Genet. Coop. Rep. 21:27-29.

Davis, A. R., Perkins-Veazie, P., Sakata, Y., Lopez-Galarza, S., Maroto, J. V., Lee, S.-G., Huh, Y.-C., Sun, Z., Miguel, A., King, S. R., Cohen, R., Lee, J.-M. 2008. Cucurbit grafting. Crit. Rev. Plant Sci. 27:50-74.

Egel, D. S., and Martyn, R. D. 2007. Fusarium wilt of watermelon and other cucurbits. The Plant Health Instructor. doi:10.1094/PHI-I-2007-0122-01.

Everts, K. L., Egel, D. S., Langston, D., and Zhou, X.-G. 2014 Chemical management of Fusarium wilt of watermelon. Crop Prot. 66:114-119.

Gusmini, G., Song, R., and Wehner, T. C. 2005. New sources of resistance to gummy stem blight in watermelon. Crop Sci. 45:582-588.

Keinath, A. P. 2001. Effect of fungicide applications scheduled to control gummy stem blight on yield and quality of watermelon fruit. Plant Dis. $85: 53-58$. 
Keinath, A. P. 2011. From native plants in Central Europe to cultivated crops worldwide: The emergence of Didymella bryoniae as a cucurbit pathogen. HortScience 46:532-535.

Keinath, A. P., DuBose, V. B., and Baccari, G. V. 2011. Evaluation of Catamaran and triazole fungicides alternated with mancozeb to control gummy stem blight on watermelon. Plant Dis. Manage. Rep. 5:V081.

Keinath, A. P., and Miller, G. A. 2014. Watermelon Spray Guide for 2014 (IL 86, Rev.). Clemson Univ. Coop. Ext., Clemson, SC.

Keinath, A. P., and Hassell, R. L. 2014. Suppression of Fusarium wilt caused by Fusarium oxysporum f. sp. niveum race 2 on grafted triploid watermelon. Plant Dis. 98:1326-1332.

King, S. R., and Davis, A. R. 2006. Pilot survey results to prioritize research needs in the watermelon industry. Cucurbit Genet. Coop. Rep. 28-29:4346.

Kousik, C. S., Adkins, S., Turechek, W. W., Webster, C. G., Webb, S. E., Baker, C. A., Stansly, P. A., and Roberts, P. D. 2012. Progress and challenges in managing watermelon vine decline caused by whitefly transmitted Squash vein yellowing virus (SqVYV). Isr. J. Plant Sci. 60:435-445.

Kousik, C. S., Ikerd, J. L., and Harrison, H. F. 2014. Development of pre- and postharvest Phytophthora fruit rot on watermelons treated with fungicides in the field. Plant Health Prog. 15:145-150. http://dx.doi.org/10.1094/ PHP-RS-14-0009.

Kousik, C. S., Levi, A., Wehner, T. C., and Maynard, D. N. 2015a. Cucurbitaceae (vine crops). eLS. 1-8. http://dx.doi.org/10.1002/ 9780470015902.a0003723.pub2.

Kousik, C. S., Adkins, S., Webster, C. G., Turechek, W. W., Stansly, P., and Roberts, P. D. 2015b. Influence of insecticides and reflective mulch on watermelon vine decline caused by Squash vein yellowing virus (SqVYV). Plant Health Prog. 16:43-48. http://dx.doi.org/10.1094/PHPRS-14-0040.

Kousik, C. S., Ji, P., and Quesada-Ocampo, L. M. 2015c. Fungicide rotation schemes for managing Phytophthora fruit rot of watermelon across southeastern United States (NC, SC, GA). Pages 23-24 in: Proc. 1st Int Soilborne Oomycete Conf. (Abstr.).

Latin, R. X., and Hopkins, D. L. 1995. Bacterial fruit blotch of watermelonthe hypothetical exam question becomes reality. Plant Dis. 79:761-765.

Latin, R. X. 1996. Bacterial fruit blotch. Pages 34-35 in: Compendium of Cucurbit Diseases. T. A. Zitter, D. L. Hopkins, and C. E. Thomas, eds. APS Press, St. Paul, MN.

Martyn, R. D., and Netzer, D. 1991. Resistance to races 0, 1, and 2 of Fusarium wilt of watermelon in Citrullus sp. PI-296341-FR. HortScience 26:429-432.

Martyn, R. D. 1996. Fusarium wilt of watermelon. Pages 13-14 in: Compendium of Cucurbit Diseases. T. A. Zitter, D. L. Hopkins, and C. E. Thomas, eds. APS Press, St. Paul, MN.
Martyn, R. D. 2014. Fusarium wilt of watermelon: 120 years of research. Pages 349-442 in: Horticultural Reviews: Volume 42. J. Janick, ed. John Wiley \& Sons, Inc., Hoboken, NJ.

McGrath, M. T., and Thomas, C. E. 1996. Powdery mildew. Pages 28-30 in: Compendium of Cucurbit Diseases, T. A. Zitter, D. L. Hopkins, and C. E. Thomas, eds. APS Press, St. Paul, MN.

Miguel, A., Maroto, J. V., Bautista, A. S., Baixaull, C., Cebolla, V., Pascual, B., Lopez, S., and Guardiola, J. L. 2004. The grafting of triploid watermelon is an advantageous alternative to soil fumigation by methyl bromide for control of Fusarium wilt. Sci. Hortic. 103:9-17.

Morrisey, B. 2006. NWA update. The Vineline. April 2006:7-10.

Netzer, D., and Martyn, R. D. 1989. PI 296341, a source of resistance in watermelon to race 2 of Fusarium oxysporum f. sp. niveum. Plant Dis 73:518.

Perkins-Veazie, P., Collins, J. K., Pair, S. D., and Roberts, W. 2001. Lycopene content differs among red-fleshed watermelon cultivars. J. Sci. Food Agric. 81:983-987.

SAS Institute Inc. 1999. SAS/STAT User's Guide, Version 8, SAS Institute Inc., Cary, NC.

Sitterly, W. R., and Keinath, A. P. 1996. Gummy stem blight. Pages 27-28 in: Compendium of Cucurbit Diseases. T. A. Zitter, D. L. Hopkins, and C. E. Thomas, eds. APS Press, St. Paul, MN.

Somodi, G. C., Jones, J. B., Hopkins, D. L., Stall, R. E., Kucharek, T. A., Hodge, N. C., and Watterson, J. C. 1991. Occurrence of bacterial fruit blotch in Florida. Plant Dis. 75:1053-1056.

Tian, T., Posis, K., Maroon-Lango, C. J., Mavrodiev, V., Haymes, S., Pitman, T. L., and Falk, B. W. 2014. First report of Cucumber green mottle mosaic virus on melon in the United States. Plant Dis. 98:1163.

Turechek, W. W., Kousik, C. S., and Adkins, S. 2010. Distribution of four viruses in single and mixed infections within infected watermelon plants in Florida. Phytopathology 100:1194-1203.

Wechter, W. P., Kousik, C. S., McMillan, M., and Levi, A. 2012. Identification of resistance to Fusarium oxysporum f. sp. niveum race 2 in Citrullus lanatus var. citroides plant introductions. HortScience 47:334-338.

Zhou, X. G., and Everts, K. L. 2004. Suppression of Fusarium wilt of watermelon by soil amendment with hairy vetch. Plant Dis. 88:13571365.

Zhou, X. G., and Everts, K. L. 2007. Effects of host resistance and inoculum density on the suppression of Fusarium wilt of watermelon induced by hairy vetch. Plant Dis. 91:92-96.

Zhou, X. G., Everts, K. L., and Bruton, B. D. 2010. Race 3, a new and highly virulent race of Fusarium oxysporum $\mathrm{f}$. sp. niveum causing Fusarium wilt in watermelon. Plant Dis. 94:92-98. 